\title{
Analysis of Waste Management Policy in Lamongan Regency
}

\author{
Achmad Aufa Anggarda ${ }^{1}$, Kismartini ${ }^{2}$, Augustin Rina Herawati ${ }^{3}$ \\ ${ }^{1,2,3}$ Public Administration Study Program, Faculty of Social and Political Sciences, Diponegoro University, \\ Semarang, Indonesia \\ aufaangga01@gmail.com
}

\begin{abstract}
The environment is a place where living things carry out their daily activities. Of course, in carrying out these activities, living things need a healthy environment and a comfortable atmosphere. Environmental problems are generally caused by natural events, rapid population growth, overuse of natural resources, industrialization and transportation. One of them is the waste problem. Waste produced by humans has an influence on environmental changes. The implementation of waste management is intended so that waste can be managed properly to create a clean and healthy living environment. This study aims to formulate the best alternative policy as an effort to address the problems of implementing waste management in Lamongan Regency. The research method used is descriptive qualitative method. In formulating policy alternatives using Bridgman and Davies' policy analysis process theory which consists of five stages, namely 1) Formulation of Policy Problems, 2) Formulating Goals and Targets, 3) Identifying Policy Parameters, 4) Finding Policy Alternatives and 5) Deciding Policy Alternatives Selected. The results showed that the implementation of waste management in Lamongan Regency that occurred was a problem of the amount of waste that was increasing from time to time and the amount of waste that was managed could not reach $50 \%$ of the total waste. Factors causing the problem are caused by: Inadequate fleet of facilities and infrastructure; Limited budget funds; Inadequate cleaning staff; and the level of public awareness of waste care is still low.
\end{abstract}

\section{Keywords}

policy analysis; waste management; Lamongan Regency

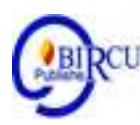

\section{Introduction}

Environmental problems are generally caused by natural events, rapid population growth, excessive use of natural resources, industrialization and transportation (Karden Edy Sontang Manik, 2007: 56). One environmental problem that is no less important is the problem of waste. According to Law No. 18 of 2008, waste is the remains of human daily activities and / or natural processes in solid form. Kuncoro Sejati (2009: 15) stated, in broad terms the types of waste can be divided into three, namely organic / wet waste, inorganic / dry waste, and hazardous waste.

The main problem in waste management is the limited ability of the government to deal with the problems of production and collection of waste which are continuously increasing. In general, only a small amount of waste can be collected and disposed of in an appropriate manner. The continuously increasing pile of garbage will have a bad effect in the future due to the increasing volume of landfills.

Waste system implemented is generally a system based on the premise of health, namely that garbage is a health hazard, so it must be immediately collected, transported and disposed of so that the impact on the environment resulting can be minimized. 
Generally the garbage transported is not thorough, but can only transport about 70$80 \%$ only. Garbage that is not carried will usually be burned, buried or dumped in sewers or in rivers, causing the flow of water to be not smooth which as a result of fatality can cause flooding.

The government in carrying out waste management must be wise in making decisions. If the government makes a wrong decision, the government itself will be overwhelmed in overcoming the waste problem.

One area that has problems with waste is Lamongan Regency, East Java Province, which is one of the cities that is developing, both in population and economy. The area of Lamongan Regency is 1,832.3 ha (Lamongan dalam Angka, 2015). The amount of waste generated in Lamongan City which is transported to the landfill in Tambakrigadung reaches $82.8 \mathrm{~m} 3$ / day with the total waste generation in Lamongan City reaching an average of 105.4 meter3 / day. Lamongan City is one of the cities that is experiencing complex problems in the field of solid waste management, especially regarding the waste transportation system. This is because the amount of waste is increasing from year to year. The amount of waste generation per day in Lamongan Regency is 2,147.63 m3 / day. The most waste generation comes from Paciran Sub district, which is $153.63 \mathrm{~m} 3$ / day.

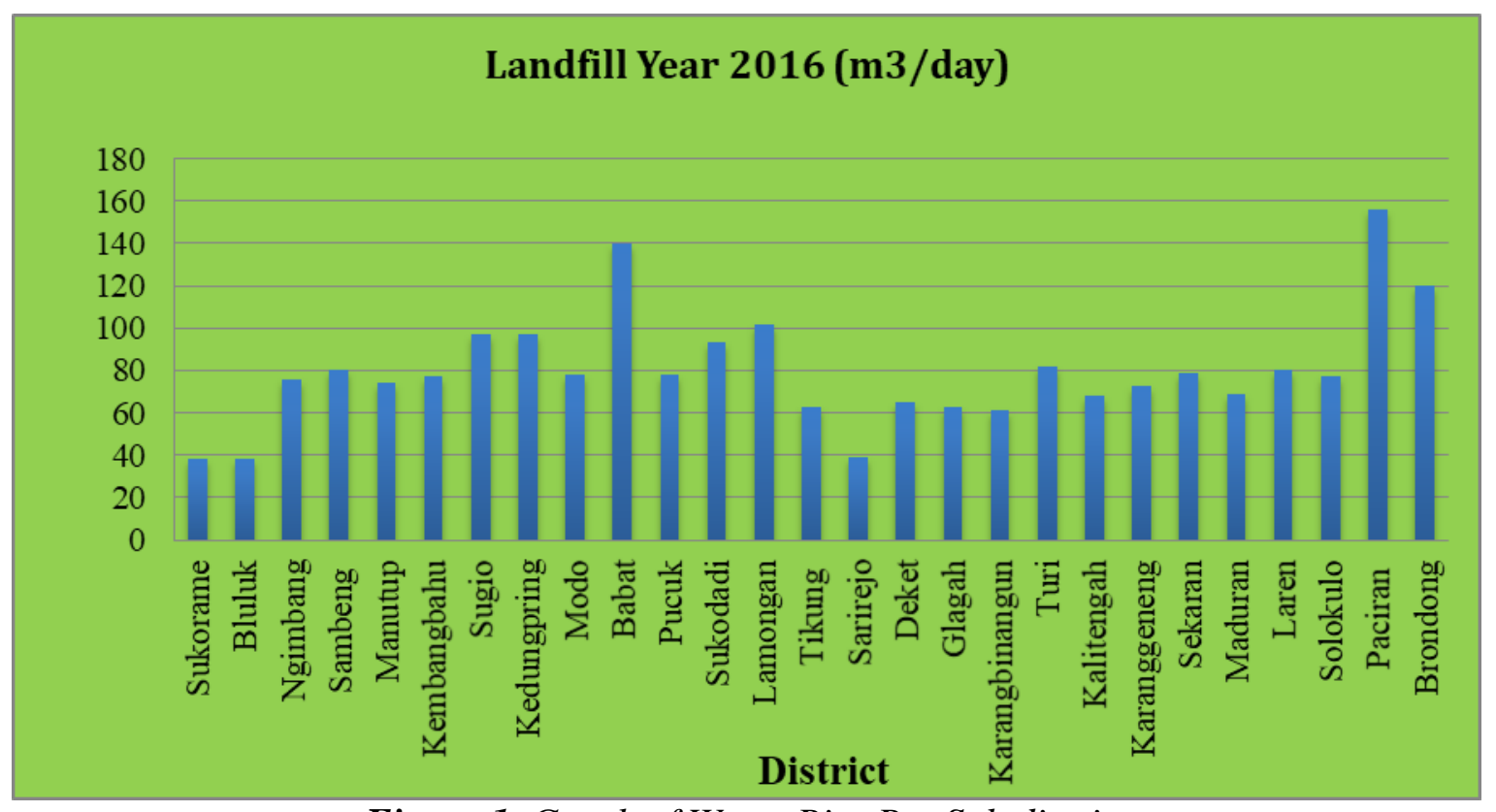

Figure 1. Graph of Waste Rise Per Sub district

Based on waste sources, the most waste is sourced from household activities, namely $1,195.36 \mathrm{~m} 3 /$ day or $55.80 \%$ of the total waste. 


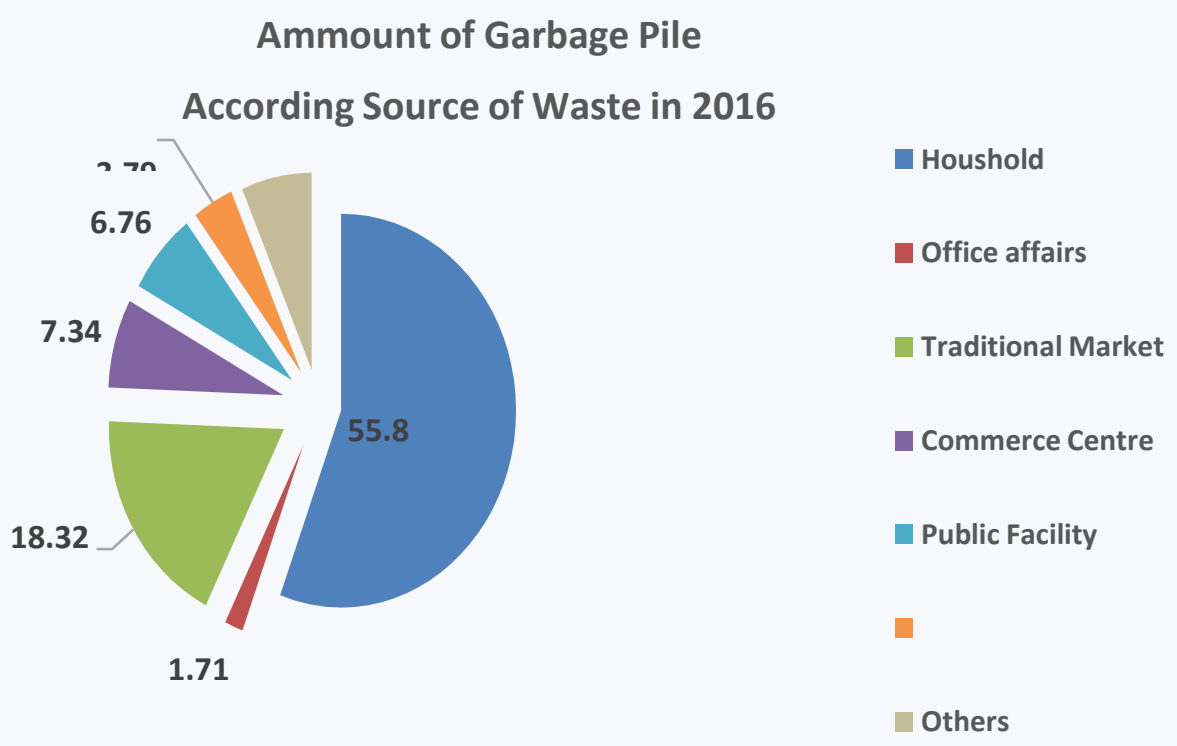

Figure 2. Data Graph of Lamongan District Waste Source

The composition of waste from Lamongan Regency is presented in Figure 2. Based on Figure 2 shows that the dominant composition of waste in Lamongan Regency is organic waste, which is $53.95 \%$, the rest consists of plastic, wood, paper, metal and so on.

\section{Waste Type Composition Diagram in 2016}
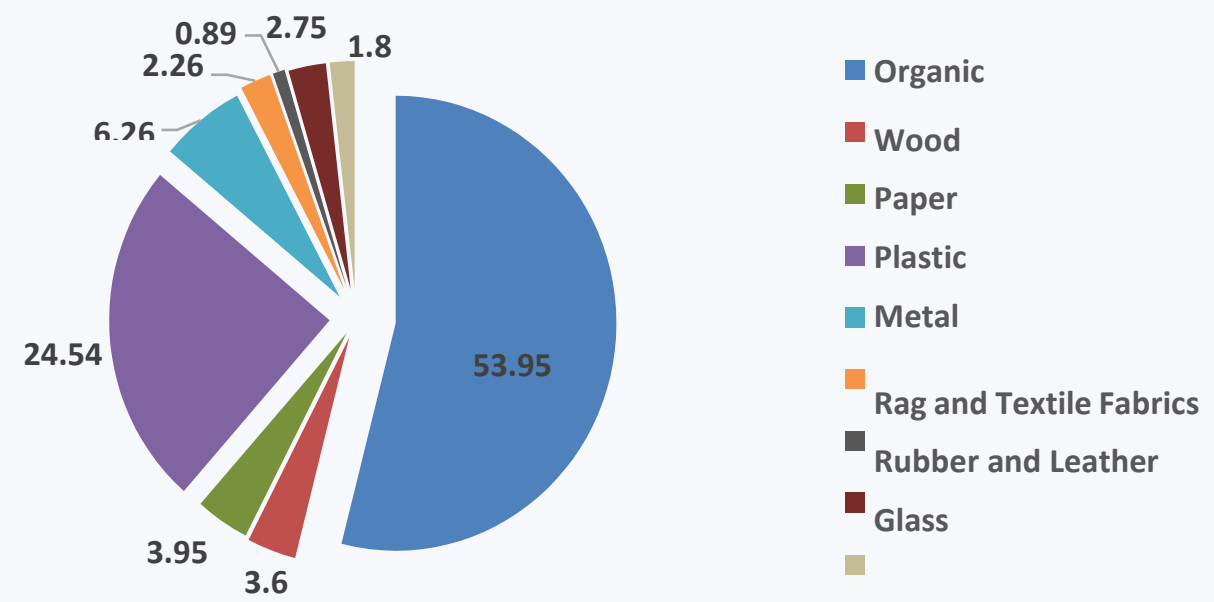

Figure 3. Composition of Waste Lamongan Regency

Meanwhile, based on the method of waste management at the household level, the average population of Lamongan Regency manages waste by throwing it into TPS, which reaches 312,948 households or around $82.9 \%$ of the total households in Lamongan Regency. 


\section{Diagram of Waste Management in Household in}
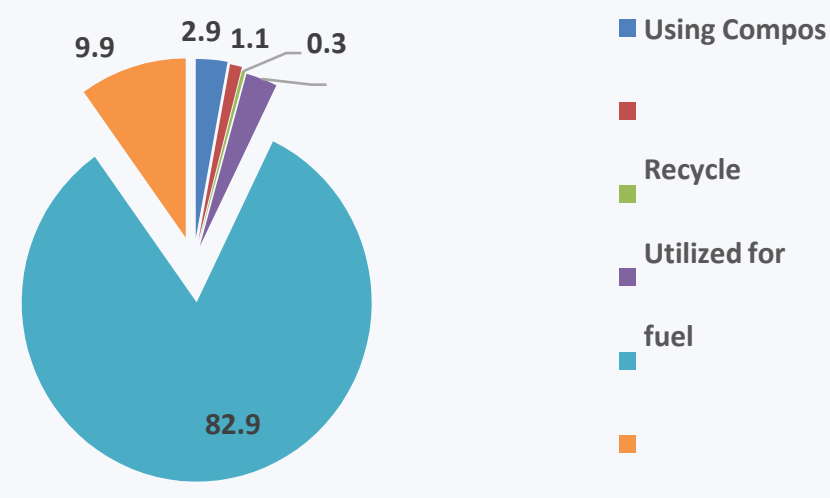

Figure 4. Diagram of How to Manage Waste in Households

To reduce the occurrence of waste in landfill, then in Lamongan District has been carried out the development of Waste Bank. The number of Waste Banks up to 2016 amounted to 1,158 units spread across RT-RT throughout the sub-district. Waste banks in Lamongan District are categorized as Advanced and Independent Waste Banks, Startup Waste Banks, and School Waste Banks. Details of the waste bank amount data are presented in the following figure:

Number of Waste Banks in 2016

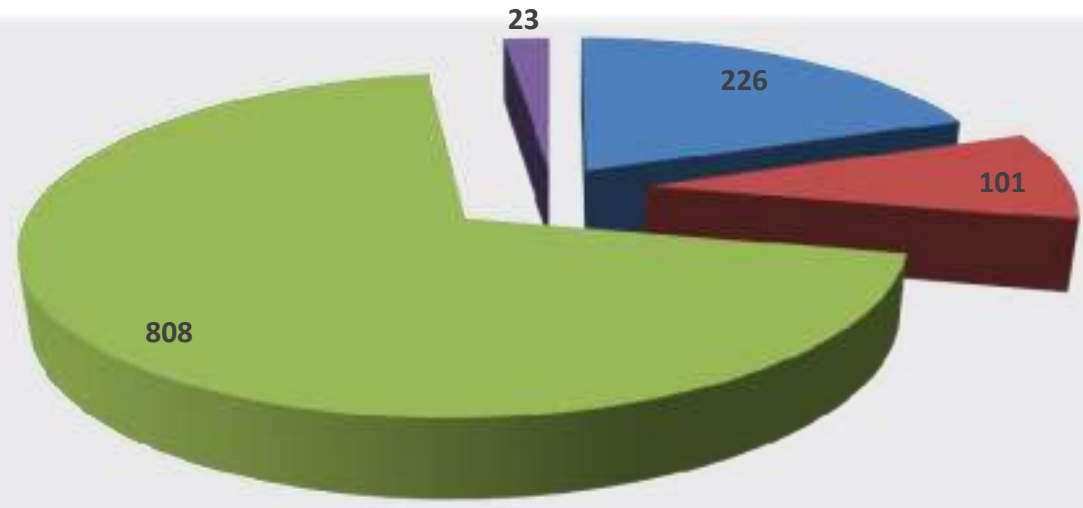

Advanced and independent waste bank (In Lamongan City)

Advanced and independent waste bank (Outside of Lamongan City)

Start-up and growing waste bank (Outside Lamongan City)

Figure 5. Waste Bank Amount Diagram 
With the existence of waste banks in Lamongan Regency, the waste reduced through waste bank activities is quite large, reaching $34.05 \mathrm{~m} 3 /$ day or reaching $2.86 \%$ of the total waste.

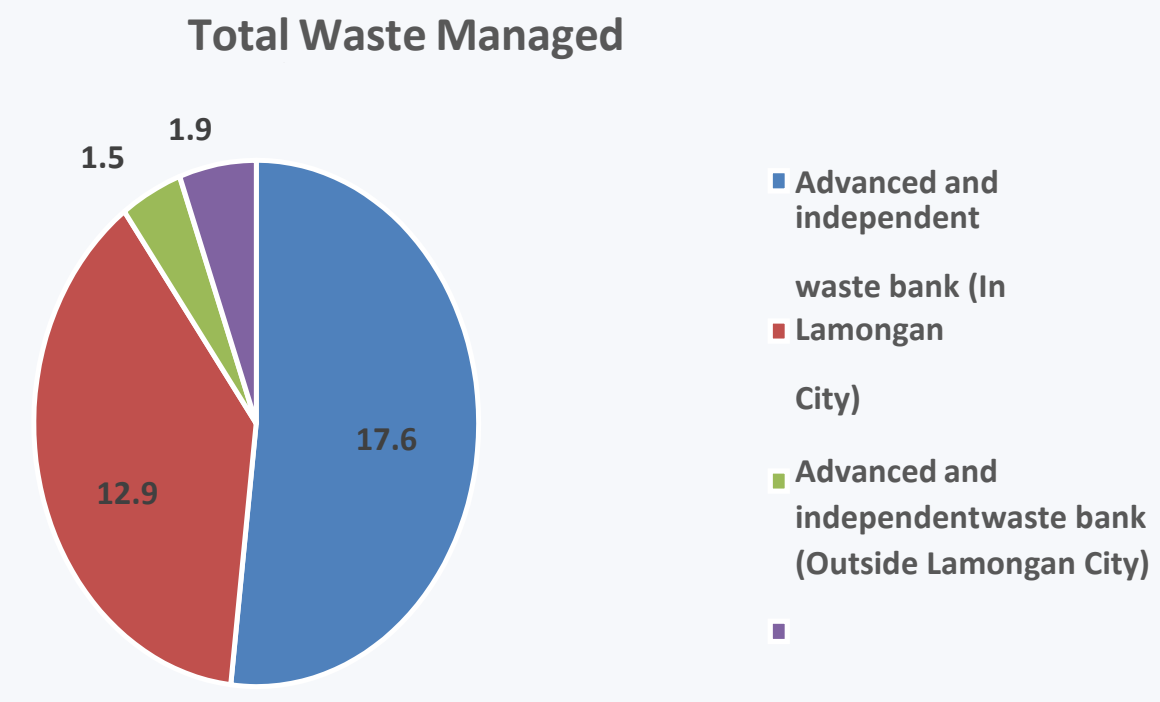

Figure 6. Waste Amount Diagram Managed by Waste Bank

The waste management policy in Lamongan City is contained in the Regional Regulation of Lamongan Regency Number 10 of 2010, concerning Waste Management in Lamongan Regency. The local government is responsible for the management of waste from the waste temporary shelter (TPS) to be collected and transported to the final disposal site (TPA) and waste management at the TPA. However, the transportation of household waste to the TPS is managed by the local RT or Village cleaning personnel (janitor). Local residents are responsible for the collection and containerization of garbage until it is placed in front of each house. The management flow can be seen in the figure below.
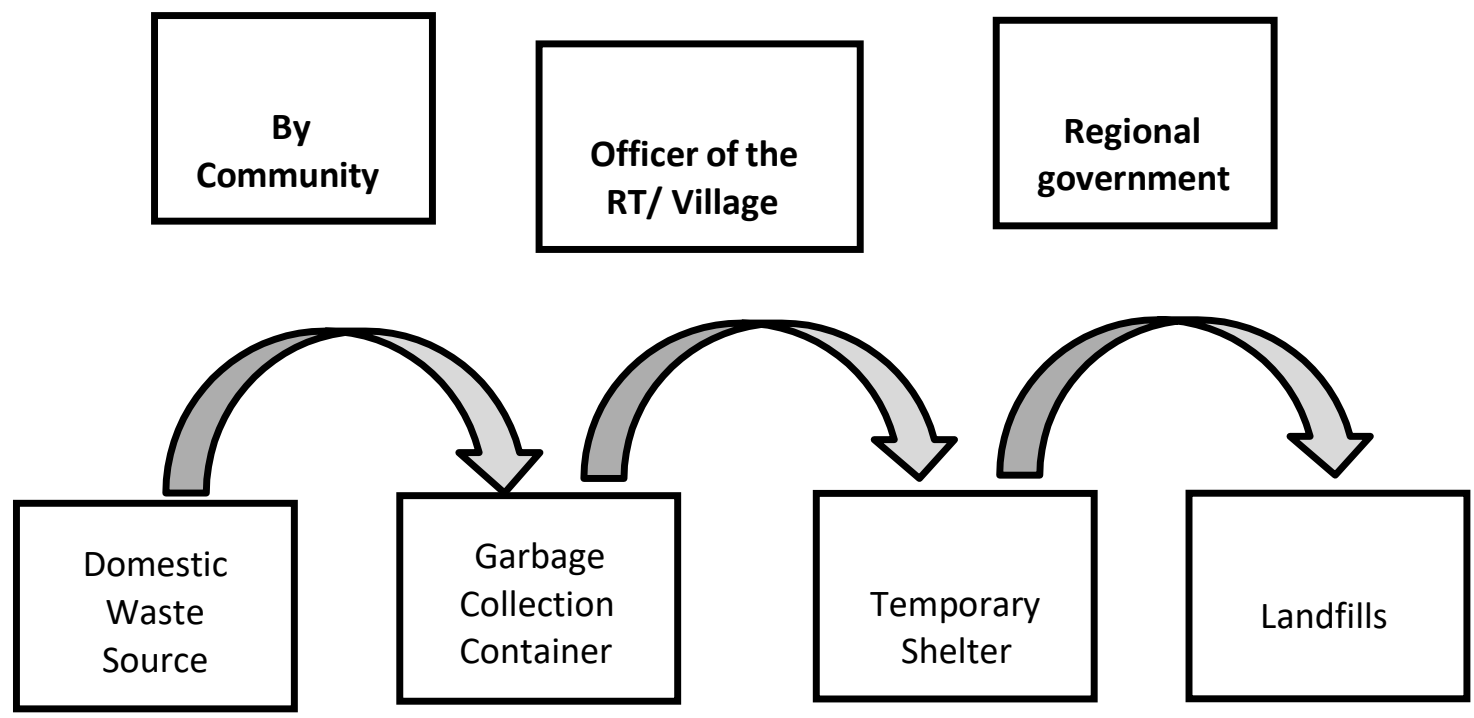

Figure 7. Flow of Waste Management in Lamongan City (Hasil Analisis, 2018) 
Based on the problems described, the authors are interested in researching the implementation of waste management in Lamongan Regency. The purpose of this study is to formulate the best alternative policy as an effort to address the problems of implementing waste management in Lamongan Regency.

\section{Review of Literature}

The process or stage of policy analysis uses 5 (five) stages in policy analysis according to Bridgman and Davis in the Book Badjuri and Yuwono (2002:65) and in Mualim and Kismartini (2008:38), which are as follows:

1) Policy Issues Formulation

The formulation of policy problems is a very principal and crucial job because if it is wrong or incorrect to focus on the problem, then the public policy to be implemented will also be incorrect. Studying a public problem requires theory, information and methodology that are relevant to the problem faced.

2) Formulation of Goals and Targets

The stage of formulating goals and objectives is important because it will determine policy priorities and actions that will be taken to overcome the problem.

3) Identifying Policy Parameters

Identification of policy parameters is an important thing in order to test or test the things that might be done in connection with a policy proposal. These policy parameters need to be explored further, especially in relation to question indicators such as: Is the policy advice delivered appropriate and relevant to current conditions? Does the policy advice presented provide a complete and possible forward looking? Can the policy advice offered anticipate anything possible in the future? Does the policy advice provided provide implications - the (political, economic, environmental and so on) implications of any alternative option? Does policy advice provide a clear and realistic strategy for a policy proposal? and Is the policy advice easy to implement?

4) Looking for Alternatives

This stage requires in-depth research. The essence of this research is to collect various data and information or relevant problems and identify various possible responses.

5) Deciding Optional Alternatives

Deciding on alternative options is the final process that must be done after the stage of finding alternatives is done. This means that the product of policy analysis is a policy recommendation that would certainly be better if more than one choice, so that the decision-making party can consider which option to decide. Complete analsis of each alternative is certainly expected.

\section{Research Methods}

This type of research is descriptive research. The research design used is descriptive qualitative research method. The efforts of this descriptive research are to describe, record, analyze and interpret the current conditions (Pasolong, 2012:75). This design is used by researchers to describe the implementation of waste management in Lamongan Regency.

The technique of selecting informants in this study used a purposive sampling system, namely the informants we got from experts who mastered waste management in the Environmental Office of Lamongan Regency, cleaners who managed waste and the people of Lamongan Regency. 
The data source in this study consists of primary data and secondary data. Data collection techniques are conducted by interview, observation and documentation methods. Data analysis used by researchers is a domain analysis technique used to obtain an overview and a thorough overview of the social situation studied (Sugiyono, 2010:256)

The problem in the policy in this study was found to finally determine policy alternatives that can be a recommendation for the Lamongan District Government, especially the Lamongan District Environment Office.

\section{Discussion}

Formulating the Best Policy Alternatives in Dealing with Waste Management Implementation Problems in Lamongan Regency:

1) Formulation of Policy Issues

The problem that occurs in the implementation of waste management in Lamongan Regency is the amount of waste that over time is increasing and the management of the amount of waste can not reach $50 \%$ of the total amount of waste available. The factors that cause problems in the implementation of waste management in Lamongan Regency are caused by: Inadequate fleet of facilities and infrastructure; Limited budget funds; Inadequate cleaning staff; and the level of public awareness of waste care is still low.

2) Formulation of Goals and Objectives

The goal to be achieved in the implementation of waste management in Lamongan Regency is to create a healthy and good living environment in order to realize sustainable development and the goal is to be able to reduce and transport the amount of waste to more than $50 \%$ of the total amount of waste.

3) Identifying Policy Parameters

a. Technical Eligibility Criteria

The thing to be achieved from the implementation of waste management in Lamongan Regency is to realize a clean and healthy environment and improve the implementation of waste management for the better.

b. Criteria for Economic and Financial Possibilities

Using currently available resources and minimal costs, the desired objectives have not been achieved.

c. Political Eligibility Criteria

The implementation of waste management in Lamongan Regency has received support from the Environmental Service and the community because it does not contradict the prevailing values and norms and the effect of the implementation of waste management in Lamongan Regency aims to create a clean and healthy and unpolluted living environment as a place to live. because this is one of the needs of society.

d. Administrative Eligibility

The Department of Environment has the authority to formulate and implement general and technical policies and to manage and use the landfill (TPA). The Environmental Agency also has a commitment to carry out duties and responsibilities in implementing waste management which has been stated in the vision and mission of the Environmental Service Office of Lamongan Regency.

4) Looking for Alternatives

a. Alternative policies for adding and improving the quality of fleet facilities and infrastructure 
The impact that arises from a technical point of view is that the fleet of waste management facilities and infrastructure has increased in number and the quality of the fleet has increased which will result in achieving the desired goals and solving the problems faced. From an economic point of view, the Regional Budget (APBD) of Lamongan Regency will be swollen and possibly the fees from waste management services will increase.

From a political perspective, there is equity and justice for regions that do not yet have waste management facilities and infrastructure. From an administrative point of view, the government through the Environment Agency has full authority in using the waste management facilities and infrastructure fleet.

b. Alternative policy of increasing the number of janitor personnel

The impact in terms of technical is the janitor in the implementation of waste management in Lamongan district increased and the quality of the janitor became better. In terms of the economy requires a large budget because if the janitor increases then the allocation of funds as the salary of the janitor is increasing.

In terms of politics, there is equality and justice for areas that are rarely visited by janitors to transport garbage in the area. Administratively, there is a neglect in terms of the capacity of the janitors.

c. Alternative policy increases the amount of budget allocation for waste management

The impact in terms of technical is the addition of the number of facilities and infrastructure fleets as well as waste management janitors. Accompanied by improved quality of the fleet of facilities and infrastructure and janitors in the implementation of waste management. In terms of the economy will make the Regional Budget (APBD) Tegal district become swollen, but the levy on waste services is improved.

In terms of politics, there is equality and justice for areas in Lamongan Regency that are far away and have little access. Administratively, only the Environment Agency has the authority to manage the budget.

d. Alternative policies for imposing sanctions on people who do not care about waste

The impact that arises from a technical point of view is to prepare a regulation on sanctions for littering. From an economic perspective, the people of Lamongan Regency can experience the benefits.

From a political point of view, the regulations regarding sanctions for littering in places get support from the government and the community.

From an administrative point of view, the Environmental Agency can provide firm intervention to communities who violate the regulations made.

5) Deciding on the Best Policy Alternatives

The alternative policy to increase the budget for waste management allocation is the best alternative policy. This is due to the ineffective condition of the implementation of waste management due to the insufficient and inadequate fleet of facilities and infrastructure and the insufficient number of cleaning personnel. The addition of the waste management allocation budget, it can make it easier to add and improve the quality of the waste management facilities and infrastructure fleet and cleaning personnel.

\section{Conclusion}

Factors causing problems in the implementation of waste management in Lamongan Regency are caused by: 1) Inadequate fleet of facilities and infrastructure, 2) Limited 
budget funds, 3) Inadequate janitors and 4) The level of public awareness of waste care is still low. In making selections of policy alternatives, Bardach criteria are used consisting of several criteria, namely: Technical Feasibility; Economic and Financial Possibilities; Political Feasibility; and Administrative Feasibility.

The alternative policy of adding and improving the quality of fleets and waste management facilities is aimed at making it easier and easier for officers to work so that the waste that is managed will increase in number. The alternative policy of increasing the number of cleaning personnel is aimed at reaching all places of access to the implementation of waste management in Lamongan Regency so that the waste in Lamongan Regency can be transported and managed entirely. The alternative policy of increasing the amount of the allocated budget is aimed at overcoming the insufficient and damaged fleet, facilities and infrastructure for waste management services. This is because with a large budget, the facilities and infrastructure fleets that are still lacking can be added and damaged fleets can be repaired or replaced with new ones if the condition of the damage is too severe. The alternative policy of imposing sanctions on people who do not care about waste aims to make the whole community aware of the dangers of garbage if it is dumped carelessly. It is hoped, of course, that the sanctions will make people more concerned about the environment.

The best alternative policy is to increase the budget for waste management allocation. This is due to the ineffective condition of the implementation of waste management due to the insufficient and inadequate fleet of facilities and infrastructure and the insufficient number of cleaning personnel. The addition of the waste management allocation budget, it can make it easier to add and improve the quality of the waste management facilities and infrastructure fleet and cleaning personnel (janitor).

\section{Recommendation}

Based on the results of the study the authors provide the following recommendations:

The alternative policy chosen is the alternative policy to increase the waste management allocation budget. Even though they have been elected, it is not certain that the alternative policy will be implemented immediately because there are many considerations. In order for policy alternatives to be implemented and their implementation according to our wishes, these policy alternatives must be supported by an implementation scenario. The following are ways that can be done so that policy alternatives can be implemented:

a) With the understanding that one party requires certain conditions, namely needs and wants, and on the other hand understands that to meet these needs and desires humans have limitations, and these limitations are opportunities for other parties to help fulfill them.

b) Identify problems in opportunities.

c) Finding ways to recast negative problems into potential opportunities and open up new opportunities for development.

d) Creating, determining and developing opportunities that can be implemented.

\section{References}

Badjuri, Abdulkaar dan Teguh Yuwono. 2002. Kebijakan Publik Konsep dan Strategi. Semarang: Undip Press.

Creswell, John W. 2014. Research Design (Pendekatan Kualitatif, Kuantitatif dan Mixed). Yogyakarta: Pustaka Belajar. 
Dinas Lingkungan Hidup Kabupaten Lamongan. 2016. Buku Laporan Informasi Kinerja Pengelolaan Lingkungan Hidup Daerah Kabupaten Lamongan. Lamongan: DLH.

Dunn, William N. 2000. Pengantar Analisis Kebijakan Publik Edisi Kedua. Yogyakarta: Gadjah Mada University Press.

Jannah Wardatul. 2020. Optimasi Rute Pengangkutan Sampah di Kota Lamongan Dengan Menggunakan Metode Saving Matrix. Indonesian Journal of Spatial Planning. 1(1).

Karden Edy Sontang Manik. 2007. Pengelolaan Lingkungan Hidup. Jakarta: Djambatan. Kuncoro Sejati. 2009. Pengolahan Sampah Terpadu. Yogyakarta: Kanisius.

Makmur dan Thahier, R. 2016. Konseptual dan Kontekstual Administrasi dan Organisasi terhadap Kebijakan Publik. Bandung: PT Refika Aditama.

Mualim, \& Kismartini. 2008. Analisis Kebijakan Penataan Pedagang Kaki Lima (Pkl) Di Simpang Lima Kabupaten Pati. Dialogue Jurnal Ilmu Administrasi Dan Kebijakan Publik, 5(1), 35-53.

Pasolong. 2012. Metode Penelitian Administasi Publik. Bandung: Alfabeta. Rahardjo Adisasmita, 2011. Pengelolaan Pendapatan dan Anggaran Daerah. Yogyakarta: Graha Ilmu.

Peraturan Daerah Kabupaten Lamongan Nomor 10 Tahun 2010 tentang Pengelolaan Sampah.

Subarsono A G. 2005. Analisis Kebijakan Publik. Konsep, Teori dan Aplikasi. Yogyakarta: Pustaka Pelajar.

Sugiyono. 2010. Metode Penelitian Bisnis (Pendekatan Kuantitiatif, Kualitatif, R\&D). Bandung: Alfabeta.

Suharno. 2013. Dasar-dasar Kebijakan Publik. Kajian Proses dan Analisis Kebijakan. Yogyakarta: Ombak.

Syafiie, Inu Kencana. 2006. Ilmu Administrasi Publik. Jakarta: PT. Rineka Cipta.

Thoha, Miftah. 2008. Ilmu Administrasi Publik Kontemporer. Jakarta: Kencana.

Undang-undang Republik Indonesia Nomor 18 Tahun 2008 tentang Pengelolaan Sampah.

Wahab, Solichin Abdul. 2012. Analisis Kebijakan. Dari Formulasi ke Penyusunan Modelmodel Implementasi Kebijakan Publik. Jakarta: PT Bumi Aksara.

Widodo, Joko. 2006. Analisis Kebijakan Publik. Konsep dan Aplikasi Analisis Proses Kebijakan Publik. Malang: Bayumedia Publishing. 